\title{
AN EXPERIMENTAL OPTIMIZATION STUDY OF A PHOTOVOLTAIC SOLAR PUMPING SYSTEM USED FOR SOLAR DOMESTIC HOT WATER SYSTEM UNDER IRAQI CLIMATE
}

\author{
Mahmoud Maustafa Mahdi ${ }^{1}$, Ameer Abed Jaddoa $^{2^{*}}$
}

\begin{abstract}
The performance of a photovoltaic solar water pumping system (PVSWPS) promising in a solar water heating system has been studied experimentally. The design of a photovoltaic array configuration can affect the performance of the (PVSWPS), the water pump characteristic, the flow rate of the water and the overall system efficiency. The aim of the present work is to determine an optimum photovoltaic array configuration that can supply a water pump with an optimal amount of energy. Three different photovoltaic array configurations have been tested $(4 \mathrm{~S}, 2 \mathrm{~S} \times 2 \mathrm{P}$ and $4 \mathrm{P})$. The experiments have been carried out in a sunny day, light hours under the conditions of Iraq climate and for a constant head level of $6 \mathrm{~m}$. The results showed that the second photovoltaic array configuration (2P $\times 2 \mathrm{~S})$ is suitable to provide an optimal energy. Also, the second photovoltaic array configuration $(2 \mathrm{P} \times 2 \mathrm{~S})$ that powered the water pump delivered a maximum average water volume $\left(2.298 \mathrm{~m}^{3}\right)$ during the day among the three different configurations.
\end{abstract}

Keywords: Photovoltaic pumping system, Photovoltaic configuration optimization, Outdoor testing, domestic hot water system

\section{INTRODUCTION}

A hot water production for house uses is produced through the years by using a device with the benefit of using solar energy; this device is called a domestic solar water heating system (DSWHS). The hot water is circulated within the system by two methods either a thermo syphon method or a force- circulation method. The latter need an electrical energy and it cannot save it. A photovoltaic solar water pumping system was introduced in order to save the electrical power that used to power the pump and to circulate the water. The photovoltaic solar pumping systems are useful for intermediate and low applications like domestic hot water systems. Many researchers over the world have been tested and studied the photovoltaic solar pumping systems[1,2]. The performance of the photovoltaic pumping systems has been tested under solar insolation and different climate conditions using various types of pump [3-5]. A hybrid system (powered by photovoltaic arrays and by wind generators) has been used in the world today. These systems are cold solar powered systems [6-8]. Experimental and theoretical studies about the photovoltaic solar pumping systems were fabricated in order to provide water for irrigation and drinking [9-13]. Studied the performance of a photovoltaic solar water pumping system [14] . A diaphragm water pump was used [15] compared the performance of a photovoltaic solar pumping system with a wind powered water pumping system. Also, [16]studied the difference in performance of fixed photovoltaic panel's one-axis tracking solar pumping system. The results showed that the power increased for tracking system in comparison with the fixed system. Additionally, [17] studied the impact of using a helical pump on the performance of a photovoltaic solar water pumping system. It was concluded that the helical pumps standard $(24 \mathrm{~V})$ crystalline silicon photovoltaic cells will be more efficient than crystalline with a high voltage, and they manifested that the helical pump improved the performance of the pumping system significantly. Developed a new version of a SWHS coupled with solar water pumping system and found that the circulated water varied from 15 to $65 \mathrm{~L}$ /day according to the discharge head and the isolation intensity [18] Presented a solar heating system coupled with a solar water pumping system and concluded that the water pump can work when the solar intensity is greater than $580 \mathrm{~W} / \mathrm{m}^{2}, 600 \mathrm{~W} / \mathrm{m}^{2}$ and $630 \mathrm{~W} / \mathrm{m}^{2}$ with a discharge head of $1 \mathrm{~m}, 1.5 \mathrm{~m}$

This paper was recommended for publication in revised form by Regional Editor Erman Aslan

1,2 Department of Electromechanical Engineering, University of Technology, Iraq-Baghdad.

*E-mail address: 50295@uotechnology.edu.iq; 50087@uotechnology.edu.iq

Orcid id: 0000-0002-5608-7980; 0000-0001-5158-1827

Manuscript Received 10 May 2019 Accepted 01 August 2019 
and $2 \mathrm{~m}$ respectively [19]. The photovoltaic system performance depends on the operating condition and the system configuration.

The condition at which the system operates depends on the system location, which governs the radiation intensity received, the outdoor temperature and other aspects that affect the performance of the system.

The system performance determines its economic and technical feasibility and whether the system represents the best solution in term of electricity sources for any given application[20]. Designed a dynamic model to estimate the performance of a solar water pumping system with energy storage. Two types of energy storage system was performed the first type (i) electric energy with a battery band and the second type (ii) hydraulic energy of stored water in a bit large tank of water. Anthers reported that a combination of both types economical and efficient solution[21]. Proposed a simple model to contribute in photovoltaic (PV) water pumping systems studies. The proposed model includes a non-linear relation between the solar power and the flow rate of the water. They found that an increase in the power of the pump leads to an increase in flow rate of the water following the proposed model [22].Investigated the performance of a photovoltaic solar water pumping system. The system consists of a PV arrays a DC motor, sun-tracker. They founded that the system performance is improved when a sun-tracker is added to the overall system [23].Presented a model of optimal sizing to optimize the different component sizes of photovoltaic solar water pumping system for irrigation and drinking in Gharadaia, Algeria. They determine an optimal configuration of the solar pumping system for different system requirements and life cycle cost [24]. In the current research, the effect of array configuration of the photovoltaic panels that can supply energy with maximum rate was selected. Therefore, it is necessary to design, test a different photovoltaic array configuration and then select a suitable configuration that can provide an optimal performance evaluation of the photovoltaic pumping system used in a domestic solar water heating system. In this study, a comparison was done in order to select the optimum photovoltaic solar water pumping system configuration, this comparison is depending on the experimental results of three different configurations. Flow rate during the day, the electrical energy of the photovoltaic array and the hydraulic energy of the pump were determined. Also, the curves that represent the efficiency of the water pump and the overall efficiency of the systems are plotted. The aim of present study is to select the photovoltaic solar water pumping system configuration that gives an optimal performance which can work in term of load demanded.

\section{EXPERIMENTAL SETUP}

The experimental test facility of photovoltaic solar water pumping system consists of a photovoltaic array of four photovoltaic modules. The photovoltaic array with $45^{\circ}$ inclination angle is configured in three different configurations. Each photovoltaic array configuration with disconnected switches contains four photovoltaic modules. The photovoltaic array is directly coupled with submersible water pump (type March 890-BR-HS 42V). The water pump is put in the lower storage tank and circulates the fluid median between the lower storage tank and the upper one; water is the fluid medium which is circulating through a piping circuit, as shown in Figure 1 (a). An experimental setup photograph of (PVSWPS) test section is shown in Figure 1(b). The measured data include the solar radiation intensity in the plane of the photovoltaic array, the water flow rate, the array output voltage and the array output current from the photovoltaic array configuration. All the measured data were half hourly averaged. Water volumetric flow rate was measured as cumulative value during each half hour. The photovoltaic module parameters are shown in Table 1. Atypical commercial photovoltaic cell has an efficiency of $15 \%$, the best efficiency of the photovoltaic module researches for different technologies was published by NREL [National Renewable Energy Laboratory] center [25] .The photovoltaic solar water pumping system was evaluated under actual climate conditions. The experimental measured data were obtained from a series of tests at University Technology in Baghdad city. The characteristics of Baghdad city are shown in Table 2. 
Journal of Thermal Engineering, Research Article, Vol. 7, No. 2, Special Issue 13, pp. 162-173, February, 2021

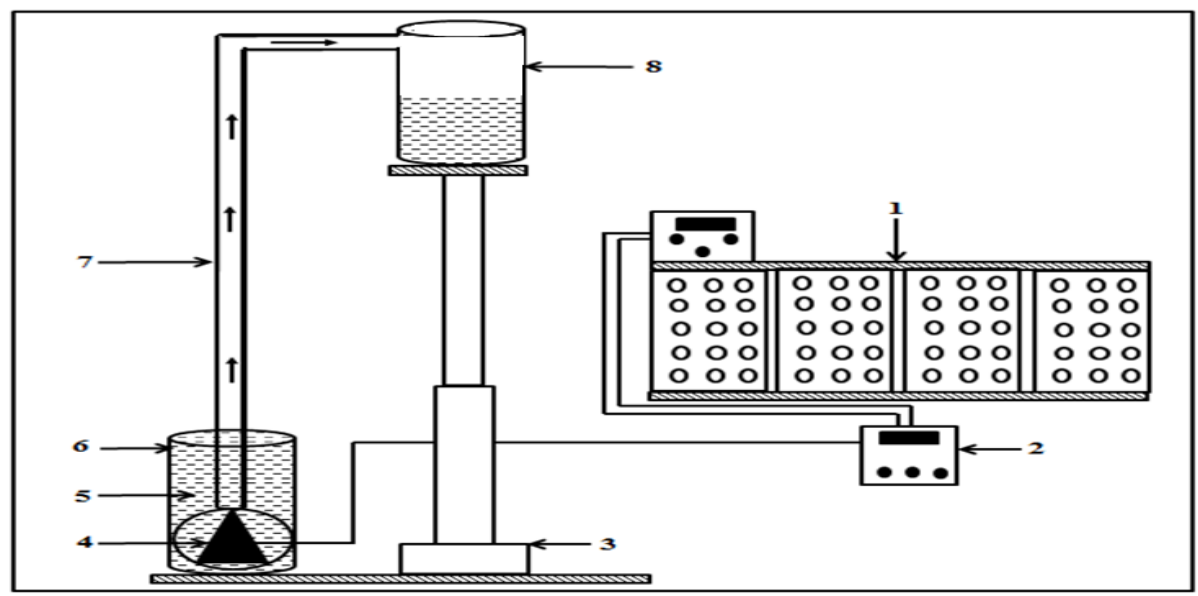

(a)

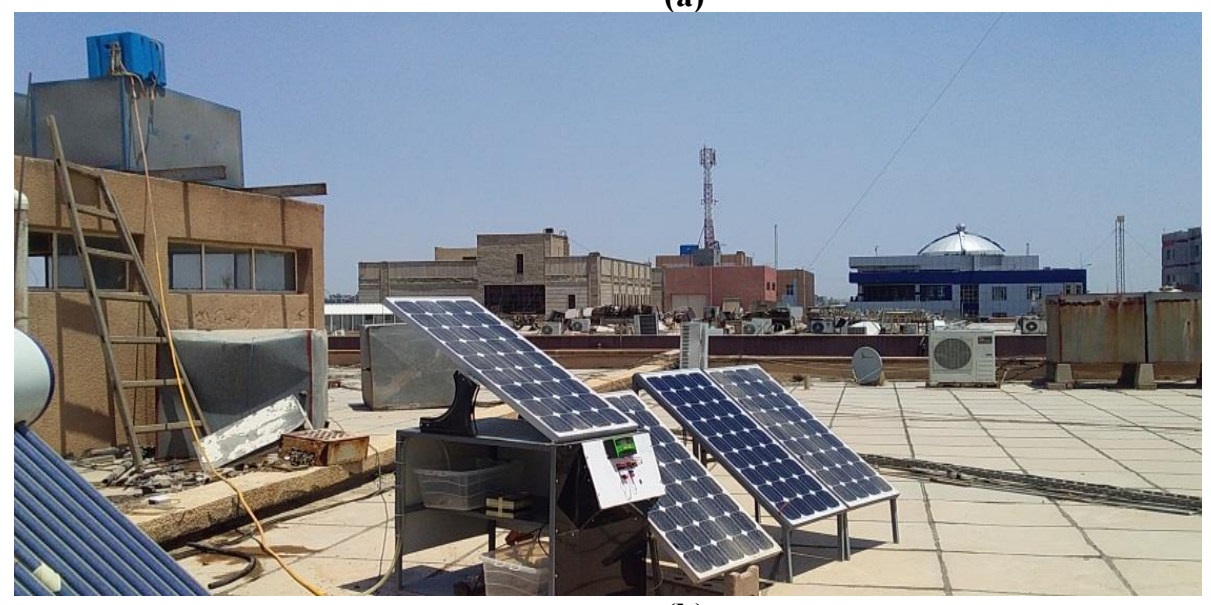

(b)

Figure 1. (a) Photovoltaic water pumping system 1-photovoltaic (300 W), 2- measurement system (V, J, W), 3Adjustable stand, 4- Water pump (type march 890 BR-HS 24 V), 5-water, 6-lower tank, 7- pipe line, 8- upper tank

(b) Photograph of (PVSWPS) test section

Table 1. Parameters of the photovoltaic module.

\begin{tabular}{|c|c|}
\hline Photovoltaic module parameter & Value \\
\hline Open circuit voltage (Voc) & $25.2 \mathrm{~V}$ \\
\hline Maximum power voltage ( $\left.\mathbf{V}_{\max }\right)$ & $20 \mathrm{~V}$ \\
\hline Short circuit current ( I sc) & $4.15 \mathrm{~A}$ \\
\hline Maximum power current ( Ipm) & $3.75 \mathrm{~A}$ \\
\hline Maximum power ( Pm) & $75 \mathrm{~W}$ \\
\hline
\end{tabular}

Table 2. Characteristic of Baghdad city

\begin{tabular}{|l|l|l|l|l|}
\hline Latitude & Longitude & Daily light & Ambient temperature & Yearly insolation \\
\hline $33.34^{\circ}$ & $44.1^{\circ}$ & $10-12 \mathrm{~h}$ & $\begin{array}{l}5^{\circ} \mathrm{C} \text { January } \\
48^{\circ} \mathrm{C} \text { August }\end{array}$ & $4.2-8.1 \mathrm{KWh} / \mathrm{m}^{2} / \mathrm{day}$ \\
\hline
\end{tabular}




\section{CHARACTERISTIC OF A PHOTOVOLTAIC CONFIGURATION}

In order to provide the required current (I) and voltage (V), a photovoltaic array, was connected in parallel, in series-parallel combination, and in series. Based on the photovoltaic modules, a proposed design of the photovoltaic array consisting of the three different configurations was selected. A $45^{\circ}$ was selected as the photovoltaic tilt angle and facing to south. The configuration of three different arrays, are namely $\mathrm{C} 1$ (4S), C2 $(2 \mathrm{C} \times 2 \mathrm{P})$ and $\mathrm{C} 3(4 \mathrm{P})$ as shown in Figure $2(\mathrm{a}),(\mathrm{b}),(\mathrm{c})$ which means:

1-) $\mathrm{C} 1$ (4S): $4 \mathrm{PV}$ modules connected in series.

2-) $\mathrm{C} 2(2 \mathrm{~S} \times 2 \mathrm{P}): 2 \mathrm{PV}$ modules connected in two parallel rows with two serial $\mathrm{PV}$ modules in each.

3-) C3 (4P): 4 PV modules connected in parallel.

The aim of the above three different configurations is to reach the optimal performance of the water pump under the three different photovoltaic array configurations tested individually. The photovoltaic arrays were put into test under the condition of a sunny day at Baghdad city. The photovoltaic arrays were tilled during testing under the outdoor conditions then the fill factors (FF) and the maximum photovoltaic array power point of, (MPP), pump efficiency $\left(\eta_{\mathrm{p}}\right)$ and the overall efficiency of the system will be determined. Maximum power point (MPP) is calculated by multiplying the maximum current and the maximum voltage that the photovoltaic array can provide at irradiance level, each photovoltaic array performance is characterized by the curve quality of its (voltage and current) sharpness. The photovoltaic energy rating has many models developed [26]. Then, the photovoltaic energy is determined by fill factor:

$$
F F=\frac{V_{m} \times I_{m}}{V_{o c} \times I_{s c}}
$$

The photovoltaic performance module can be calculated by measuring the efficiency of conversion from sunlight to electric power. The photovoltaic efficiency is determined from the output power that produced from the sun solar radiation. The photovoltaic standard measurement conditions are revered to the temperature, the area of the photovoltaic and the radiation intensity [27-29]. By making a comparison between the output energy generated by the photovoltaic array and the incident solar energy on it, the efficiency of the individual photovoltaic configuration can be determined with following relation:

$$
\eta=\frac{V_{m} \times I_{m}}{E \times A_{p v}}
$$

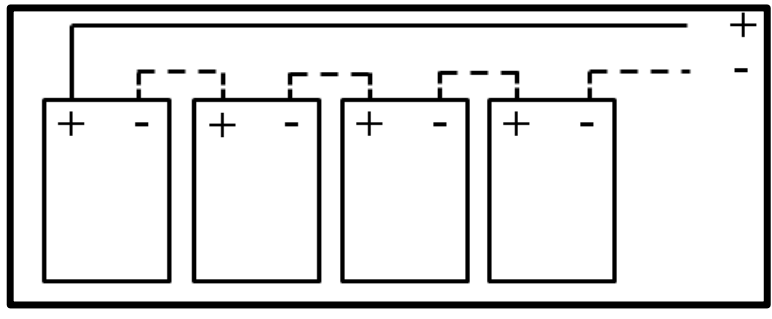

(a)

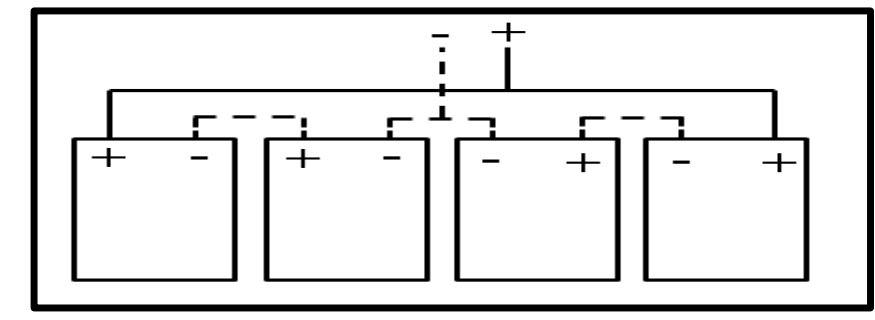

(b)

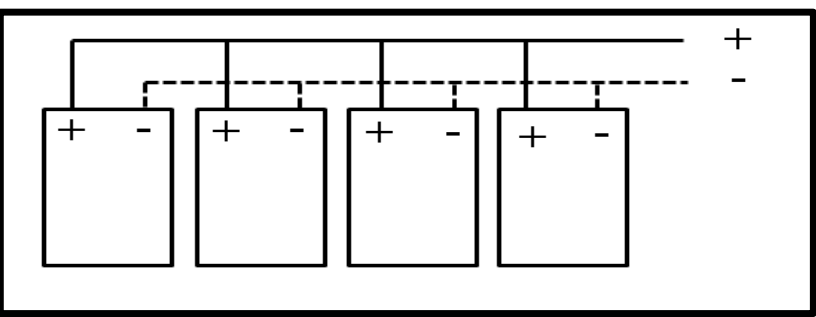

(c)

Figure 2. Photovoltaic array configurations

(a) $\mathrm{C} 1:(4 \mathrm{~s})=4$ modules connected series, (b) $\mathrm{C} 2$ : $(2 \mathrm{~s} \times 2 \mathrm{p})=4$ modules connected in Two Parallels with two serial modules in each, (c) C3 (4p) $=4$ modules connected in Parallels5 
Journal of Thermal Engineering, Research Article, Vol. 7, No. 2, Special Issue 13, pp. 162-173, February, 2021

The characteristic of three different photovoltaic array configurations is shown in Table 3 .

Table 3. Characteristic of three different photovoltaic array configurations.

\begin{tabular}{|l|c|c|c|c|c|c|}
\hline \multicolumn{1}{|c|}{$\begin{array}{c}\text { Pv } \\
\text { configuration }\end{array}$} & $\begin{array}{c}\text { Shunt } \\
\text { Isc (A) }\end{array}$ & $\begin{array}{c}\text { Open voltage } \\
\text { Voc (v) }\end{array}$ & $\begin{array}{c}\text { Power } \\
\mathbf{( W ) ~ p m}\end{array}$ & $\begin{array}{c}\mathbf{A}_{\mathbf{p v}} \\
\mathbf{m}^{\mathbf{2}}\end{array}$ & $\mathbf{F F}$ & $\begin{array}{c}\boldsymbol{\eta}_{\mathbf{p v}} \\
\mathbf{\%}\end{array}$ \\
\hline $\begin{array}{l}\mathrm{C} 1 \text { in series } \\
4\end{array}$ & 4.15 & 100.8 & 300 & 4.34 & 70.1 & 14.4 \\
\hline $\begin{array}{l}\text { C2 in parallel } \\
2 \text { in series }\end{array}$ & 8.2 & 50.4 & 300 & 4.34 & 70.3 & 14 \\
\hline $\begin{array}{l}\text { C3 } \\
4 \text { in parallel }\end{array}$ & 16.4 & 25.2 & 300 & 4.34 & 70.1 & 15.17 \\
\hline
\end{tabular}

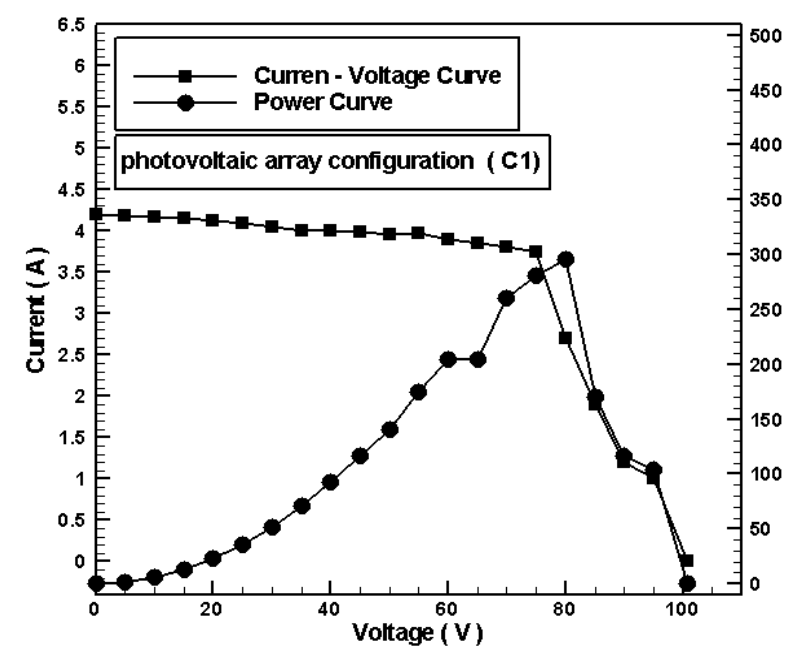

(a)

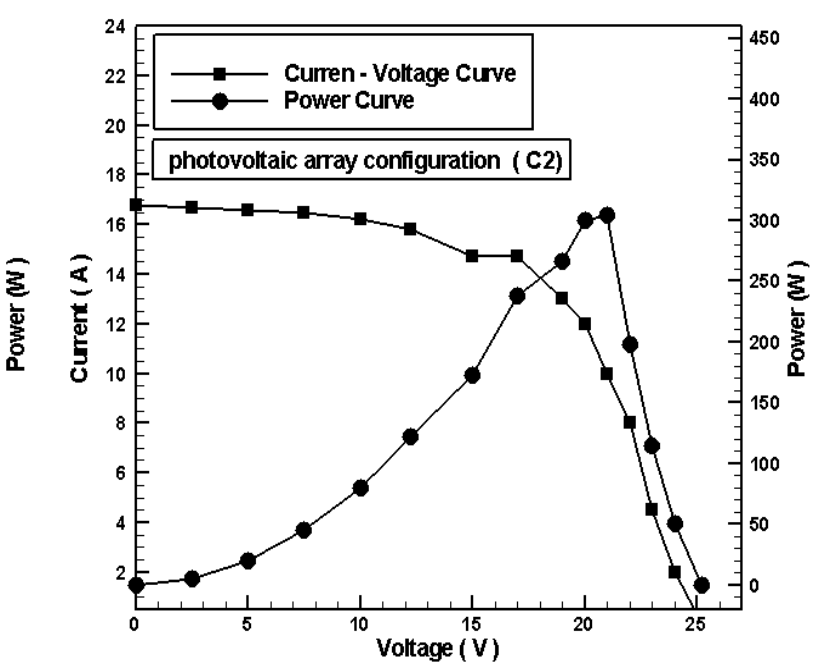

(b)

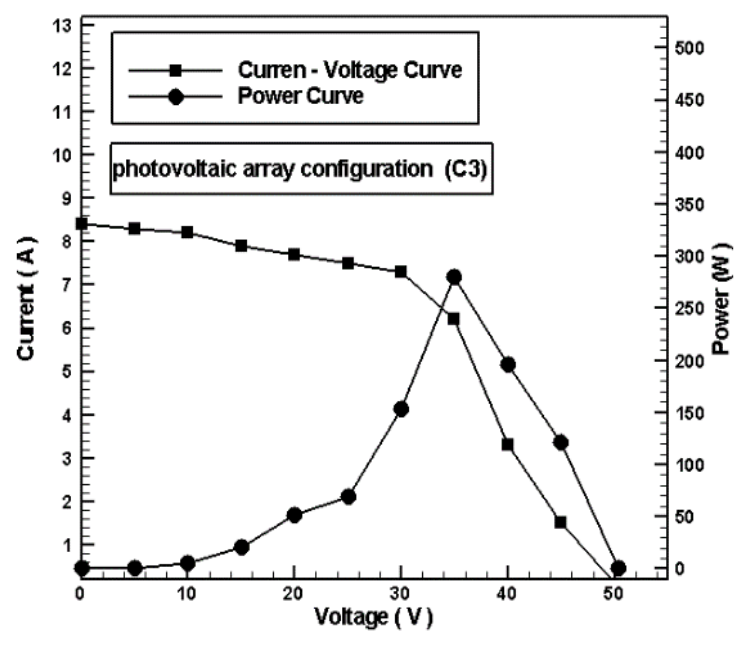

(c)

Figure 3. (a), (b), (c). Characteristics curves of three different photovoltaic array configurations. 
Journal of Thermal Engineering, Research Article, Vol. 7, No. 2, Special Issue 13, pp. 162-173, February, 2021

The uncertainty of the various instrument and physical properties are given in Table 4 .

Table 4. Uncertainties of the measuring instruments

\begin{tabular}{|c|c|c|c|c|}
\hline No & Rang & Instruments & Frequency & uncertainty \\
\hline 1 & {$[0-150] \mathrm{V}$} & Digital voltmeter & 50 & $\pm 0.06 \mathrm{~V}$ \\
\hline 2 & {$[0.1-20] \mathrm{A}$} & Digital Ammeter & 50 & $\pm 31 \times 10^{-3}$ \\
\hline 3 & {$[5-25] \mathrm{L}$} & Small volume proverb & - & $\pm 0.15 \%$ \\
\hline 4 & $0-1100 \mathrm{~W} / \mathrm{m}^{2}$ & CM11 Pyrometer & - & $\pm 0.6 \%$ \\
\hline
\end{tabular}

\section{METHODOLOGY}

In the present work, the pump is powered by the photovoltaic array configuration. A fixed head of $(6 \mathrm{~m})$ was chosen for the testing the water pump during the sunny days (April 2018). Each configuration was tested along three days. The measured power output, the volumetric flow rate of the water, the current and the voltage of the circuit and solar radiation intensity were measured, a typical solar intensity variation during the day is shown in Figure 4 . For each array configuration, the electrical energy, pumping hydraulic energy the energy received by the photovoltaic surface area, pump efficiency and the overall efficiency of the system were determined. The pumping consumes a daily electrical energy, which can be determined by the power integration (during the operating period $11.5 \mathrm{hr}$ ) demanded by the water-pump. This integration is given by the following equation:

$$
E_{e}=\int_{\mathrm{hr}=6.5}^{h r=18} p . d t
$$

The pump provides a hydraulic energy during the day, and it can be determined by the following equation:

$$
E_{h}=C_{h} \times H \int_{\mathrm{hr}=6.5}^{h r=18} Q . d t
$$

The amount of the energy received by the photovoltaic array that incidents on the surface area of it and during the daylight hours is calculated by the following equation:

$$
E_{i}=A_{p r} \int_{\mathrm{hr}=6.5}^{h r=18} E \cdot d t
$$

The efficiency of the water pump is obtained by dividing the pump hydraulic energy equation (4) by the photovoltaic electrical energy equation (3). This is given by the following equation:

$$
\eta=\frac{E_{h}}{E_{e}}
$$

While, the overall efficiency of the system is determined by dividing the hydraulic energy of the pump equation (4) by the incident radiation energy on the surface area of the photovoltaic during the operating time and it is given by the following equation:

$$
\eta_{\text {overall }}=\frac{E_{h}}{E_{i}}
$$


Journal of Thermal Engineering, Research Article, Vol. 7, No. 2, Special Issue 13, pp. 162-173, February, 2021

This optimal configuration can reach the maximum volumetric flow rate of water.

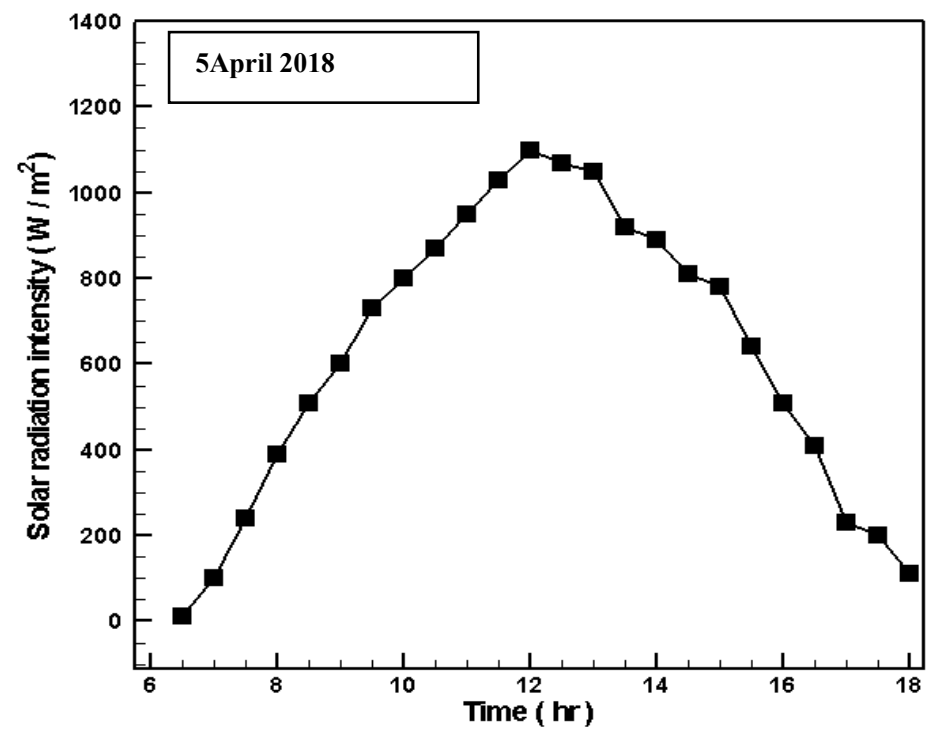

Figure 4. Typical solar radiation intensity during a sunny day

\section{RESULTS AND DISCUSSION}

Experiments were conducted with the aim of evaluating the behavior of a photovoltaic solar water pumping system (PVSWPS). The photovoltaic array system with three different configurations was tested. From the results of experimental data of the three different (PVSWPS) configurations, a comparison analysis is first carried out to obtain the overall performance of each configuration. The next step is to select the appropriate optimal design among photovoltaic array configurations.

Table 4 displays the results of the three different (PVSWPS) configurations, (PVSWPS1), (PVSWPS2) and (PVSWPS). The average volume of the water during the day was between $\left(1.7 \mathrm{~m}^{3}\right.$ and $\left.2.3 \mathrm{~m}^{3}\right)$, for different configurations $(\mathrm{C} 1, \mathrm{C} 2$, and $\mathrm{C} 3)$.

Table 4. Performance of the photovoltaic solar-water pumping system.

\begin{tabular}{|c|c|c|c|c|c|c|}
\hline $\begin{array}{l}\text { photovoltaic } \\
\text { configuration }\end{array}$ & $\begin{array}{c}\text { Maximum } \\
\text { flow rate } \\
\left(\mathrm{m}^{3} / \text { day }\right)\end{array}$ & $\begin{array}{l}\text { Maximum } \\
\text { power }(W)\end{array}$ & $\begin{array}{c}\text { Maximum } \\
\text { pump } \\
\text { efficiency } \\
\left(\eta_{p} \%\right)\end{array}$ & $\begin{array}{c}\text { Average } \\
\text { pump } \\
\text { efficiency } \\
\left(\eta_{\text {avp } \%)}\right.\end{array}$ & $\begin{array}{c}\text { Maximum } \\
\text { system } \\
\text { efficiency } \\
\left(\eta_{\text {sys }} \%\right)\end{array}$ & $\begin{array}{c}\text { Average } \\
\text { system } \\
\text { efficiency } \\
\left(\eta_{\text {a sys }} \%\right)\end{array}$ \\
\hline $\begin{array}{c}\mathrm{C} 1 \\
(4 \mathrm{~s})\end{array}$ & 1.79 & 117.1 & 72.2 & 42.47 & 7.12 & 3.61 \\
\hline $\begin{array}{c}C 2 \\
(2 s \times 2 p)\end{array}$ & 2.298 & 152.4 & 67.6 & 46.51 & 7.44 & 4.22 \\
\hline $\begin{array}{c}\text { C3 } \\
(4 p)\end{array}$ & 1.811 & 167.7 & 58.3 & 36.14 & 8.92 & 4.69 \\
\hline
\end{tabular}

From the obtained results of the performance of the system and through the three different configurations comparison, there is an attempt trying to select the most optimal system configuration. This optimal configuration can be able to reach the maximum volumetric rate of water. Firstly the comparison of the volumetric water flow rates and the electric power supplied by the three (PVSWPS) configuration $(\mathrm{C} 1, \mathrm{C} 2$ and $\mathrm{C} 3$ ) is made. A comparison between the three different configurations at the same level head is depicted in Figure 5. This figure reveals the three 
curves which represent the variation of the daily volumetric water flow rates supplied by the three different photovoltaic solar water pumping system configurations. Also, this figure elucidates that the provided volumetric flow rate by the $(\mathrm{C} 2)$ configuration is the most significant around the mid of the day and a maximum value is reached, while the volumetric water flow rate supplied by the other two configurations ( $\mathrm{C} 1$ and $\mathrm{C} 2)$, significantly less than the volumetric water flow rate provided by the photovoltaic solar water systems. The volumetric water flow rate supplied by $(\mathrm{C} 1$ and $\mathrm{C} 3)$ configurations has a maximum values at the early morning operating time and then remains constant through the whole operating time.

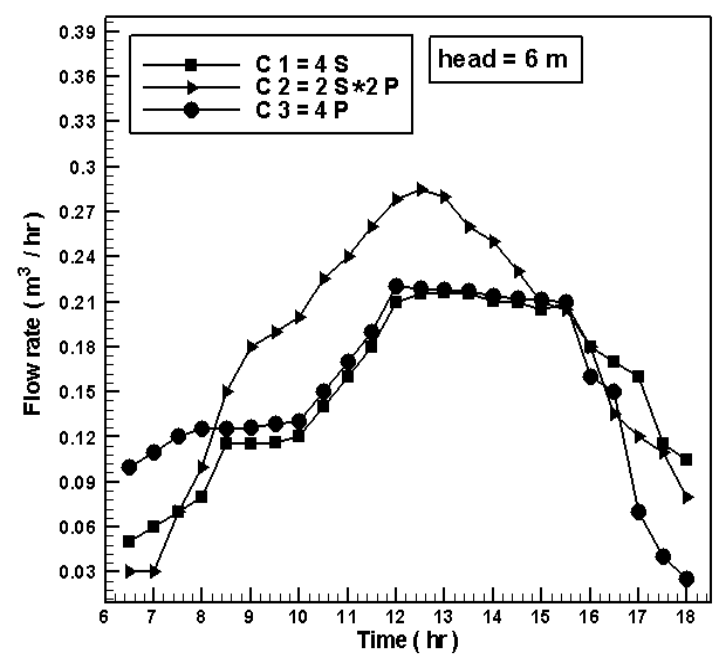

Figure 5. The variation of volumetric flow rates during the day.

Figure 6 evinces the variation in the corresponding electrical powers with time of the day provided for the three photovoltaic solar water pumping system configurations $(\mathrm{C} 1, \mathrm{C} 2, \mathrm{C} 3)$. This figure represents the typical electrical power distribution of the photovoltaic module. There is a sharply steep electrical power gradient between $(6.5 \mathrm{hr})$ and $(8 \mathrm{hrs})$, and the electrical power reaches its maximum values in the early morning. After this period, the electrical power is nearly constant in the model operation time. A second drop in the electrical power is noticed at the late day light hours, approximately, at $16 \mathrm{hr}$. The second photovoltaic configuration (C2) provides appropriate and enough electrical current, due to its parallelism arrangement, this can lead the photovoltaic array to meet the operating point of the pump. When the pump meets the operating point, this allows it to reach the maximum power of the pump quickly at the begging ours of the day, i.e. rapid increase, then the pump still operates constant rate till the hours of the late daylight time, at which the power dropped rapidly (a steep drop in the power level). The power provided by the third configuration (C3) is over the maximum power of the pump. The second step is to make a comparison study of the pumping system efficiency for the three different configurations (C1, C2 and C3). This comparison is made in terms of the efficiency of the pump and the overall efficiency of the system trend.

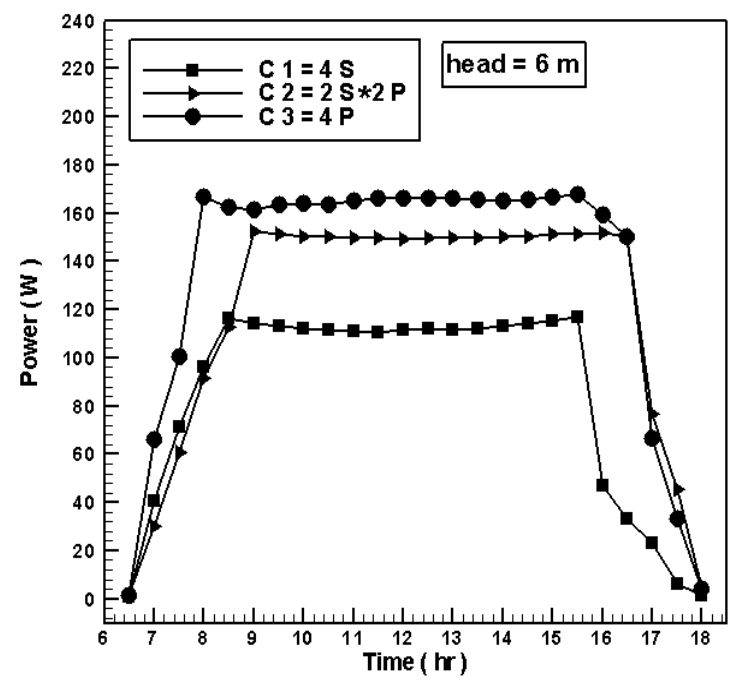

169

Figure 6. Variation of electrical powers with time of the day. 
Figure 7 (a), (b), (c)(demonstrates the efficiency of the pump curves of the three different photovoltaic configurations ( $\mathrm{C} 1, \mathrm{C} 2$ and $\mathrm{C} 3$ ), respectively. This figure is plotted at the water level head of $6 \mathrm{~m}$. From this figure, it can be noticed that in the early morning and in the late day light, the pumping system achieves the same values of efficiency.

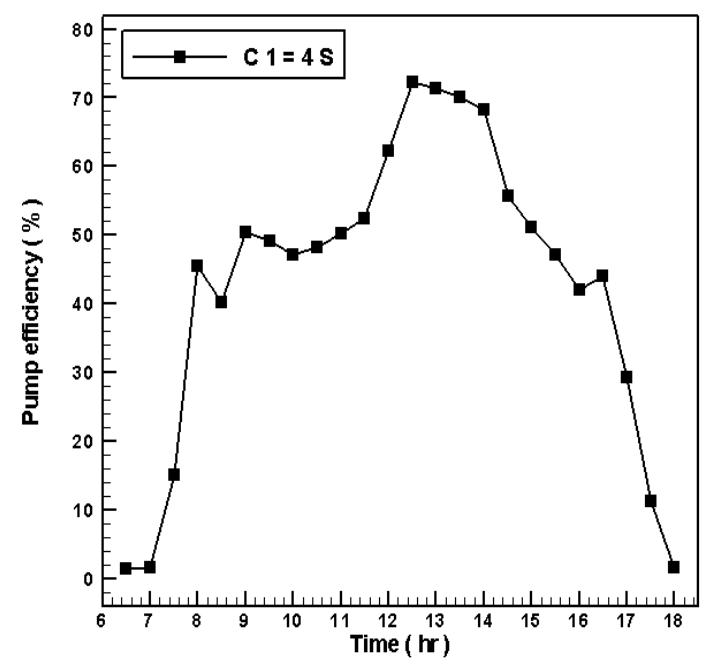

(a)

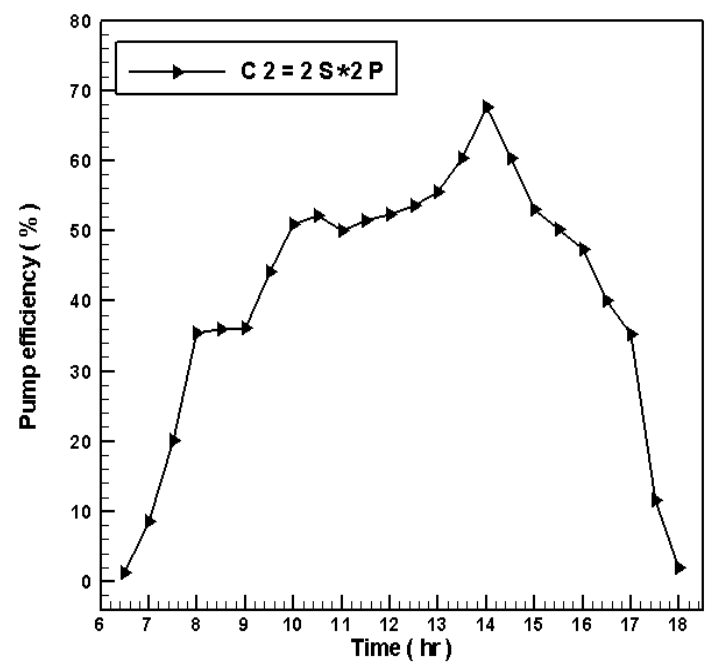

(b)

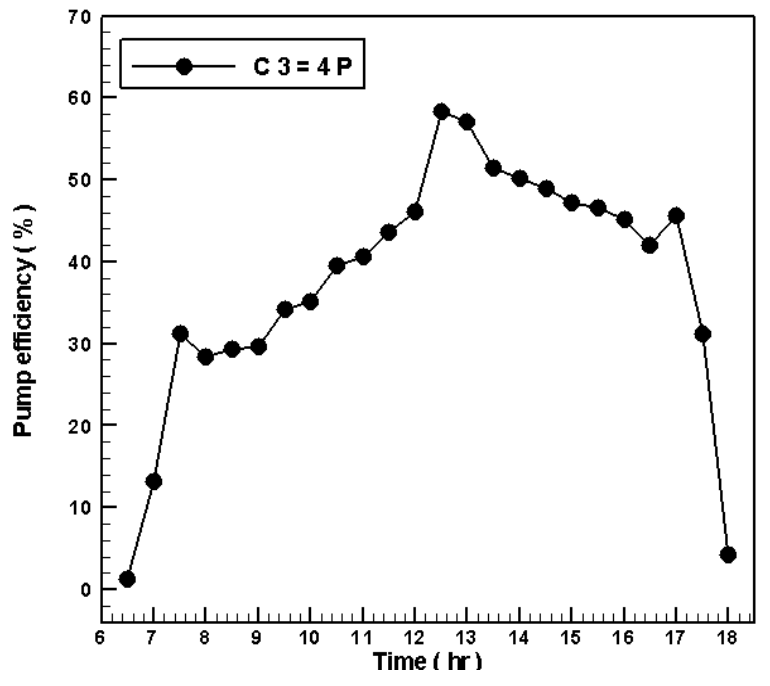

(c)

Figure 7. (a), (b), (c) Variation of pump efficiency for three different photovoltaic configurations during the day.

The second photovoltaic pumping system configuration (C2) provides a pumping efficiency more significant than the pumping efficiency that provided by the other two configurations ( $\mathrm{C} 1$ and $\mathrm{C} 3$ ). Table 4 exhibits briefly the outline results including the average pumping efficiency. It is observed from this table that the second photovoltaic pumping system configuration provides the best average pumping efficiency and the maximum water flow rate during the day $\left(2.298 \mathrm{~m}^{3} /\right.$ day). In order to assess the effect of the photovoltaic configuration on the overall system efficiency Figure 8(a), (b), (c) is plotted. This figure illustrates the variation of the overall system efficiency during the operation period for ahead level of $6 \mathrm{~m}$. This figure clarifies a comparison of the overall system efficiency 
the three different photovoltaic configurations. It can be noted from this figure that the second photovoltaic solar water pumping system configuration (C2) provides an overall efficiency with a significant and constant values along the operating period hours of the days except at the early morning hours and at the late ours afternoon. The overall efficiency of the system that is provided by the first photovoltaic pumping system configuration (C1) is less significant through the day time except in the early morning hours and in the late afternoon hours, at which the overall efficiency marked higher efficiency level.

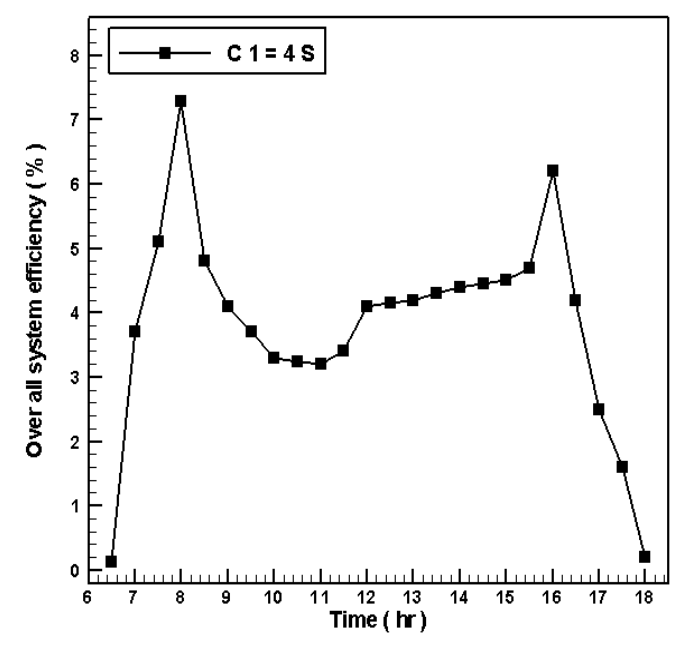

(a)

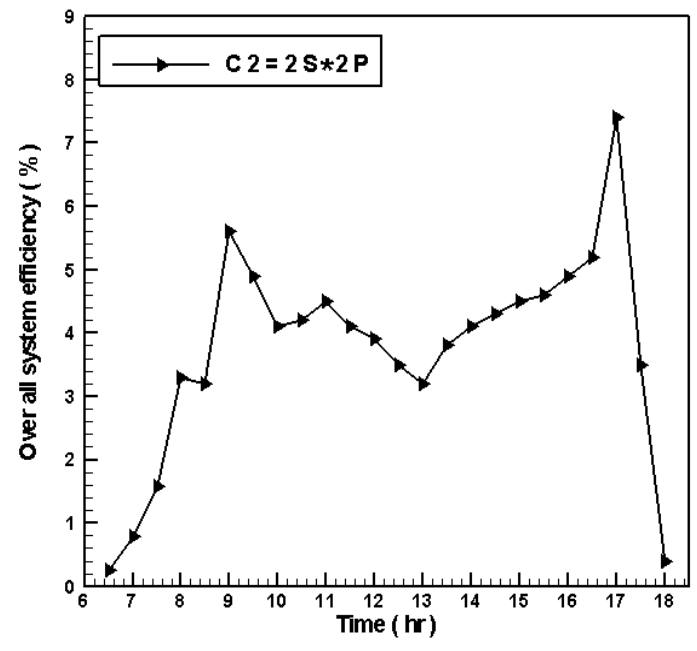

(b)

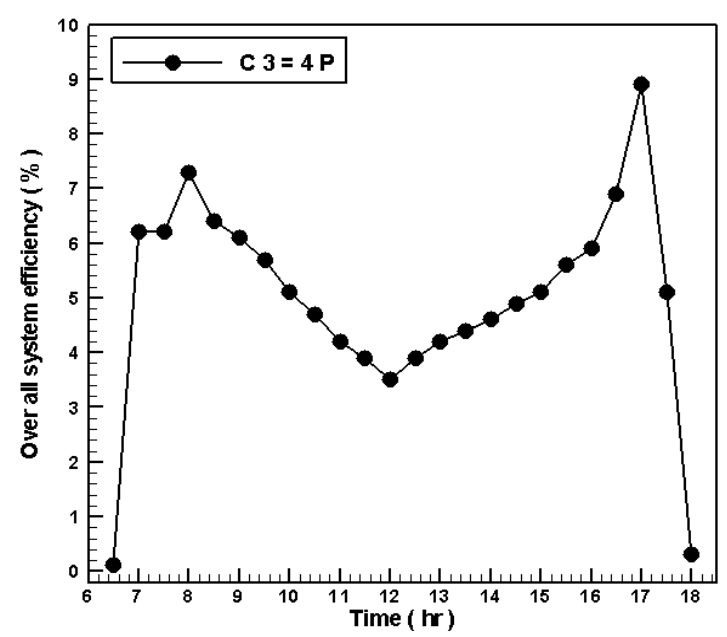

(c)

Figure 8. (a), (b), (c) Overall system efficiency for three configurations (C1, C2 and C3) along operating time.

\section{CONCLUSION}

An experiment was carried out on a photovoltaic solar water pumping system to study its performance under three different photovoltaic module configurations. In general, the photovoltaic solar pumping system is sensitive to the variation of the solar irradiance failing on the photovoltaic array and the voltage and current that needed to run the pumping load.

Besides, the volume of water provided by the photovoltaic module configuration of the second configuration (C2) is more significant around noon when compared with the other two photovoltaic system 
Journal of Thermal Engineering, Research Article, Vol. 7, No. 2, Special Issue 13, pp. 162-173, February, 2021

configurations. The maximum average water volume delivered the first array configuration (C1), second array configuration $(\mathrm{C} 2)$, and third configuration $\left(\mathrm{C} 3\right.$ were $1.79 \mathrm{~m}^{3}, 2.289 \mathrm{~m}^{3}$ and $1.811 \mathrm{~m}^{3}$ respectively. Also, the second system configuration (C2) is suitable for supplying a maximum flow of water through the daily operating period daily period.

Furthermore, the overall system efficiency with the second photovoltaic configuration (C2) is more appropriate in comparison with the tow photovoltaic array systems during the optimum sun light. That means, in order to run the pumping system, the photovoltaic configuration (C2) is an appropriate choice.

\section{NOMENCLATURE}

$\mathrm{A}_{\mathrm{pr}} \quad$ Area of photovoltaic array, $\mathrm{m}^{2}$.

E Solar energy intensity, $\mathrm{W} / \mathrm{m}^{2}$.

$\mathrm{E}_{\mathrm{e}} \quad$ Pump electric power, $\mathrm{Wh} /$ day

FF Fill factor.

$\mathrm{I}_{\mathrm{m}} \quad$ Maximum current of the pump, A.

P Pump power required, W.

Q Water flow rate, $\mathrm{m}^{3} / \mathrm{s}$.

$\mathrm{V}_{\text {oc }} \quad$ Photovoltaic array open circuit voltage, V.

$\eta_{\mathrm{p}} \quad$ Pump efficiency, \%.

$\mathrm{C}_{\mathrm{h}} \quad$ The constant $=9800 \mathrm{Kg} / \mathrm{m}^{2} \mathrm{~s}^{2}$.

$\mathrm{E}_{\mathrm{i}} \quad$ Energy of incident solar radiation, Kwh/day.

$E_{h} \quad$ Hydraulic energy of the pump, Wh/day.

$\mathrm{H} \quad$ Water level head, $\mathrm{m}$.

$\mathrm{I}_{\mathrm{sc}} \quad$ Photovoltaic array short circuit current, A.

$\mathrm{P}_{\mathrm{m}} \quad$ Photovoltaic array maximum power.

$\mathrm{V}_{\mathrm{m}} \quad$ Pump nominal voltage, $\mathrm{V}$.

$\eta_{\mathrm{pv}} \quad$ Photovoltaic array efficiency, $\%$.

$\eta_{\text {overall }}$ Overall system efficiency, $\%$.

\section{REFERENCES}

[1] Ghoneim AA. Design optimization of photovoltaic powered water pumping systems. Energy Convers Manag 2006;47:1449-1463. https://doi.org/10.1016/j.enconman.2005.08.015.

[2] Amer EH, Younes MA. Estimating the monthly discharge of a photovoltaic water pumping system: Model verification. Energy Convers Manag 2006;47:2092-2102. https://doi.org/10.1016/j.enconman.2005.12.001.

[3] Hadj Arab A, Benghanem M, Chenlo F. Motor-pump system modelization. Renew Energy 2006;31:905-913. https://doi.org/10.1016/j.renene.2005.06.003.

[4] Moechtar M, Juwono M, Kantosa E. Performance evaluation of a.c. and d.c. direct coupled photovoltaic water pumping systems. Energy Convers Manag 1991;31,6:512-527.https://doi.org/10.1016/01968904(91)90087-Y.

[5] Metwally HMB, Anis WR. Dynamic performance of directly coupled photovoltaic water pumping system using D.C. shunt motor. Energy Convers Manag 1996;35:1405-1416.https://doi.org/10.1016/01968904(95)00226-X.

[6] Grassie T, MacGregor K, Muneer T, Kubie J. Design of a PV driven low flow solar domestic hot water system and modeling of the system collector outlet temperature. Energy Convers Manag 2002;43,8:1063$1078 \mathrm{https}: / /$ doi.org/10.1016/S0196-8904(01)00090-5.

[7] Lara DD, Merino GG, Pavez BJ, Tapia JA. Efficiency assessment of a wind pumping system. Energy Convers Manag 2011;52:793-803. https://doi.org/10.1016/j.enconman.2010.08.004.

[8] Anagnostopoulos JS, Papantonis DE. Pumping station design for a pumped-storage wind-hydro power plant. Energy Convers Manag 2007;48,11:3009-3017. https://doi.org/10.1016/j.enconman.2007.07.015.

[9] Mokeddem A, Midoun A, Kadri D, Hiadsi S, Raja IA. Performance of a directly-coupled PV water pumping system. Energy Convers Manag 2011;52,10:3089-3095 . https://doi.org/10.1016/j.enconman.2011.04.024.

[10] Skretas SB, Papadopoulos DP. Systematic procedure for efficient design of electric water pumping systems 
Journal of Thermal Engineering, Research Article, Vol. 7, No. 2, Special Issue 13, pp. 162-173, February, 2021

fed by PV or/and WECS: Application using measured meteorological data for the city of Xanthi/Thrace, Greece. Energy Convers Manag 2008;49,4:595-607. https://doi.org/10.1016/j.enconman.2007.07.043.

[11] Alajlan SA, Smiai MS. Performance and development of PV - Plant for water pumping and desalination for remote area in Saudi Arabia. Renew Energy 1996;8,1-4:441-446.https://doi.org/10.1016/09601481(96)88895-1.

[12] Benghanem M, Hadj Arab A. Photovoltaic water pumping systems for Algeria. Desalination 2007;290,1:5057. https://doi.org/10.1016/j.desal.2007.04.008.

[13] Benghanem M, Arab AH, Mukadam K. Data acquisition system for photovoltaic water pumps. Renew Energy 1999;17,3:385-396. https://doi.org/10.1016/S0960-1481(98)00126-8.

[14] Hadj Arab A, Chenlo F, Benghanem M. Loss-of-load probability of photovoltaic water pumping systems. Sol Energy 2004;76,6:713-723. https://doi.org/10.1016/j.solener.2004.01.006.

[15] Anis WR, Nour MA. Optimum design of a photovoltaic powered pumping system. Energy Convers Manag 1994;35,12:1123-1130. https://doi.org/10.1016/0196-8904(94)90016-7.

[16] Clark RN. Photovoltaic water pumping for livestock in the Southern Plains. Am. Soc. Agric. Eng. Meet., 1994; 94-4529.

[17] Vick BD, Clark RN. Performance of wind-electric and solar-pv water pumping systems for watering livestock. J Sol Energy Eng Trans ASME 1996;18:212-216. https://doi.org/10.1115/1.2871780.

[18] Vick BD, Clark RN. Determining the optimum solar water pumping system for domestic use, livestock watering or irrigation. 38th ASES Natl. Sol. Conf. 2009, Sol. 2009, 2009.

[19] Vick BD, Clark RN. Water pumping performance of a solar-PV powered helical pump. Proc. Sol. World Congr. 2005 Bringing Water to World, Incl. Proc. 34th ASES Annu. Conf. Proc. 30th Natl. Passiv. Sol. Conf., 2005.

[20] Sutthivirode K, Namprakai P, Roonprasang N. A new version of a solar water heating system coupled with a solar water pump. Appl Energy 2009;86:1423-1430. https://doi.org/10.1016/j.apenergy.2008.12.002.

[21] Biswas S, Iqbal MT. Dynamic Modelling of a Solar Water Pumping System with Energy Storage. J Sol Energy 2018;84:1-12.https://doi.org/10.1155/2018/8471715.

[22] Benghanem M, Daffallah KO, Almohammedi A. Estimation of daily flow rate of photovoltaic water pumping systems using solar radiation data. Results Phys 2018;8:949-954 https://doi.org/10.1016/j.rinp.2018.01.022.

[23] Kolhe M, Joshi JC, Kothari DP. Performance analysis of a directly coupled photovoltaic water-pumping system. IEEE Trans Energy Convers 2004;19: 613-618. https://doi.org/10.1109/TEC.2004.827032.

[24] Argaw N. Optimisation of photovoltaic water pumps coupled with an interfacing pulse width modulated DC/AC inverter power conditioning device. Conf. Rec. IEEE Photovolt. Spec. Conf., 1994. https://doi.org/10.1109/wcpec.1994.520170.

[25] Roonprasang N, Namprakai P, Pratinthong N. Experimental studies of a new solar water heater system using a solar water pump. Energy 2008;33:639646. https://doi.org/10.1016/j.energy.2007.12.002.

[26] Kracker U, Pienitz S. Ermittlung von Photovoltaik-Referenzprofilen. Ew -- Mag F $\{\ddot{u}\} r$ Die Energiewirtschaft 2017.

[27] Kroni R, Stettler S, Friesen G, Chianese D. Energy rating of solar modules-final report 2005.

[28] Kenny RP, Friesen G, Chianese D, Bernasconi A, Dunlop ED. Energy rating of PV modules: Comparison of methods and approach. Proc. 3rd World Conf. Photovolt. Energy Convers., 2003.

[29] Mohanty P, Muneer T, Gago EJ. Solar Photovoltaic System Applications. 2016. https://doi.org/10.1007/9783-319-14663-8. 